\title{
Evaluation of the fulfillment of educational rights for children in conflict with the law through the filial school program
}

\author{
Ahmad Zulinto ${ }^{1^{*}}$, Syukri Hamzah ${ }^{2}$, Hadiwinarto Hadiwinarto ${ }^{2}$ \\ ${ }^{1}$ Universitas PGRI Palembang, Indonesia \\ ${ }^{2}$ Universitas Bengkulu, Indonesia
}

\begin{tabular}{l}
\hline Article Info \\
\hline Article history: \\
Received Aug $22^{\text {nd }}, 2021$ \\
Revised Sept $23^{\text {rd }}, 2021$ \\
Accepted Oct $12^{\text {th }}, 2021$ \\
\hline
\end{tabular}

\section{Keyword:}

Filial school program

Education right

Children in conflict with the law

Palembang

Evaluation research

\begin{abstract}
The Palembang City Government through the Education Office in collaboration with the Regional Office of the Ministry of Law and Human Rights of South Sumatra Province as well as with other stakeholders initiated the implementation of Filial Schools Services for Child Prisoners at LPKA Class I Palembang. This study aimed at evaluating Filial Schools Filial Schools for Child Prisoners at LPKA Class I Palembang. This was evaluation research with a qualitative approach and using CIPP model. Data collection in this research was through observation, interviews, and documentation. The subjects of this study consisted of an accompanying teacher, a party from the Education Office, and a student. The data were analysed using Miles and Huberman model. The validity of the research data was obtained by using triangulation techniques by comparing the data from interviews, observations, and documentation. The study found that the fulfillment of educational right for children in conflict with the law through the Filial School Program at LPKA Class 1 Palembang has been going well. Based on the monitoring results, most of the children who have completed their education at LPKA have been able to improve their welfare. The Filial school program in providing the right to formal education for children through Quality Formal Education Services for Children at LPKA Class I Palembang has been going well. This program also presents the same curriculum as formal schools, also equipped with character building, as well as the development of various skills in students.
\end{abstract}

(C) 2021 The Authors. Published by IICET.

This is an open access article under the CC BY-NC-SA license

(https://creativecommons.org/licenses/by-nc-sa/4.0)

\section{Corresponding Author:}

Ahmad Zulinto,

Universitas PGRI Palembang

Email: drahmadzulinto@gmail.com

\section{Introduction}

In the Preamble of the Constitution of the Republic of Indonesia 1945, one of the National Goals of the Republic of Indonesia is contained in the fourth paragraph "to educate the life of the nation", this can be realized through fair, equitable, and quality education. Education is a process that becomes the control in realizing a peaceful, democratic, just, competitive, advanced, and prosperous Indonesian society within the unitary State of the Republic of Indonesia, this is in line with the definition in the Dictionary of Education, Fattah (2004) explained that education is "the whole process by which a person develops abilities, attitudes, and other forms of behavior that have positive values in the society in which he lives so that education will deliver a quality society (Limpo et al, 2018). 
The right to education of every citizen has been regulated in the Republic of Indonesia Law Number 20 of 2003 concerning the National Education System in article 5 paragraph (1) "that every citizen has the same right to obtain quality education", including children. For children in conflict with the law, who are undergoing a period of coaching and mentoring at LPKA, of course, they have the right to obtain an education as regulated in the Law of the Republic of Indonesia Number 12 of 1995 concerning Corrections, article 14 (Sopandi \& Khasanah, 2020).

In-Law Number 20 of 2003 concerning the National Education System, Article 4 number 1 states "Education is carried out in a democratically and fair manner and is not discriminatory by upholding human rights, religious values, cultural values, and the value of national pluralism". So that the education of children who are in conflict with the law in LPKA must be the same as for children in general. Meanwhile, if a child carries out his punishment in LPKA, the educational process carried out by the child will be different from children in general who are not carrying out a punishment in LPKA. If children who are not convicted get an education in public schools, then children who are convicted will get an education in LPKA. This is because the child's right to freedom is taken away by the state (Estriyanto, 2016).

Based on data from the Directorate General of Corrections of Indonesia in 2014, the implementation of non-formal education programs and equality education for children in conflict with the law in Indonesia has only reached $24 \%$ of the number of children who have been convicted, while in the city of Palembang it has only reached $14 \%$ children who are still neglected, so that efforts to foster and build character and restore good names for children dealing with the law are not optimal (Bappeda Litbang, 2019).

In relation to these conditions, by upholding the spirit of the Sustainable Development Goals (SDGs) "No One Left Behind" meaning that no child is left behind in getting a quality education, the Palembang City Government through the Education Office in collaboration with the Regional Office of the Ministry of Law and Human Rights of South Sumatra Province and together with other stakeholders initiated the implementation of Filial Schools for Child Prisoners at LPKA Class I Palembang. This initiative aims to provide equal opportunities for every child, especially for child prisoners in LPKA Class I Palembang to get a quality formal education so that it has an impact on increasing the Human Development Index of Palembang City, especially in the aspect of education, the average length of schooling continues shows a rising graph. This also indicates an increase in the quality of education in the city of Palembang. There are three main problems behind the birth of this filial school (Bappeda Litbang, 2019), namely: (1) Package program education at LPKA Class I Palembang has not provided equal rights for children in LPKA; and (2) Package education has not contributed much to increase knowledge, skills, and behavior change; and (3) the low interest of children in LPKA Class I Palembang in participating in the package program education (A, B), the number is only $14 \%$ of children in LPKA.

Filial Schools for Child Convicts at LPKA Class I Palembang is one of the leading innovations for the Palembang city area with education levels ranging from Elementary School, Junior High School, and Senior High School. The Palembang City Education Office as the implementing institution for the Education program in Palembang City, South Sumatra Province in collaboration with the Regional Office of the Ministry of Law and Human Rights of South Sumatra Province, since 2014 has implemented formal education services for children who conflict with the law through the implementation of filial school programs, namely at LPKA Class I Palembang.

Children are assets for national development whose rights should be fought for to get a proper education to produce quality human resources in the future. Without measurable quality, national development will be difficult to implement and the fate of the nation will be difficult to imagine (Hidayat, 2010). Angelina's research (2013) regarding the fulfillment of the right to formal education for children in conflict with the law as an effort to create a Child-Friendly City in Surakarta. The research concludes that the fulfillment of the right to formal education for children in conflict with the law in Surakarta, which is developing a Child-Friendly City is still hindered by various problems, including weak family resilience, lack of public knowledge about handling of children in conflict with the law, and the unequal perspective of children's rights among stakeholders. The community tends to hand over the handling of children in conflict with the law to law enforcement officers so that from hundreds of thousands of children in conflict with the law, two-thirds of them end up with imprisonment (Supeno, 2010).

Children are buds, potentials, and the younger generation who will succeed the ideals of the nation's struggle, have a strategic role, and have special characteristics and nature that ensure the continuity of the existence of the nation and state in the future. For every child to be able to take on these responsibilities, he needs to have the widest opportunity to grow and develop optimally, physically, mentally, and socially and has a noble character treatment without discrimination (Djamin, 2013). Several previous studies found that at 
the Class IIA Children's Prison Tanjung Gusta Medan, the fulfillment of the right to education for child prisoners was not fully provided by the child's rights as it should be (Tambunan, 2015). Legal protection of the rights of Correctional Students in the coaching process at the Kutoarjo Class I correctional institution for children is still lacking, especially in terms of facilities (Nugroho, 2018). The national education system should be able to guarantee education for all, including children in conflict with the law. Solving various problems and seeking protection for children, opening access to education for all children, especially children in conflict with the law is a must if you want to see Indonesian children grow and develop as obsessed with the Convention on the Rights of the Child (Supeno, 2010).

Based on the explanation above, the authors were interested in evaluating the implementation of the Filial School Program at LPKA towards the fulfillment of the right to education for children in conflict with the law in Indonesia. Educational evaluation is a type of education system that tries to assess the educational process over time. The purpose of the evaluation is to better understand, investigate, and improve the educational process so that any gaps in deficiencies that need to be addressed can be identified and addressed. Therefore, educational evaluation is needed to develop a competent education system, namely an education system that is continuously improved by correcting deficiencies that arise. The aims of this study were to: 1) find out the results of the evaluation of the Filial School program at the Class 1 Correctional Institution for Children Palembang; 2) find out the factors supporting and inhibiting the success of the Filial School program at the Class 1 Correctional Institution for Children of Palembang.

\section{Method}

This was evaluation research with a qualitative approach. The evaluation model chosen was CIPP, which stands for Context evaluation, Input Evaluation, Process Evaluation, and Product evaluation. The CIPP model has an orientation to provide services to various models of community service programs and policies. This evaluation model aims to link information, context, inputs, and processes with the product, as well as to show the availability of the environment to achieve the goals and objectives of the program being implemented (The Regulation of Minister Education, 49, 2014). The CIPP model was used because this evaluation model can be carried out structurally and significantly (Hasan, 2009). In addition, the CIPP model was used because the effectiveness of this evaluation model could be measured to obtain formative and summative results as well as the ability to solve problems that occur. Based on these conditions, research was conducted that focused on the CIPP model framework to obtain a framework to assist in evaluating the implementation of the system. The context, input, process, and product evaluation model (CIPP) was developed by Stufflebean et al. (2003). The uniqueness of this model lies in the fact that in each type of evaluation there are decisions made regarding the planning and operation of a program. This model also sees that a program is evaluated as a system, and this model is an evaluation model that has several advantages compared to other program evaluation models (Sukardi, 2014), (Widoyoko, 2009), (Zhang et al, 2011). The advantages are: 1) provides a very detailed or broad picture of a project, 2) has the potential to work in the formative and summative fields, 3) is more comprehensive or more complete in filtering information, 4) can provide a good basis for decision making and policies to design future programs. Another advantage is that the CIPP evaluation model provides a comprehensive evaluation format that is comprehensive at each evaluation stage (Gunung et al, 2019).

Data collection in this research was through observation, interviews, and documentation. The subjects of this study consisted of a tutor, an accompanying teacher, a party from the Education Office, and a student who participated in the program. The selection of research subjects was carried out by the purposive sampling method, meaning that the participants who were asked for information were participants who had gone through certain considerations to achieve the expected goals. The data analysis used in this study was the Miles and Huberman model (Sugiyono, 2016). The validity of the research data was obtained by using triangulation techniques, namely by comparing the data from interviews, observations, and documentation.

\section{Results and Discussions}

\section{Program policy}

Since 2014 the Government of Palembang City together with the Regional Office of the Ministry of Law and Human Rights of South Sumatra Province have been committed to providing quality education rights for children in conflict with the law in LPKA Class I Palembang, through a Cooperation Agreement in the field of education as the basis for implementing Filial Schools at LPKA Class I Palembang and in 2016 it was further strengthened by a Cooperation Agreement between the Director General at the Ministry of Education and Culture of the Republic of Indonesia and the Director-General of Social Affairs at the Ministry of Law and Human Rights of the Republic of Indonesia. Many parties collaborated on the implementation of this Filial 
school program, related parties namely the South Sumatra Ministry of Law and Human Rights, Indonesian Family Planning Program, the South Sumatra Province Youth and Sports Office, and the Palembang City and Provincial Education Office which then appointed public schools not far from LPKA Palembang, namely State Elementary School 25 Palembang, State Junior High School 22 Palembang, and State Senior High School 11 Palembang.

The determination of the main schools is determined by the city and provincial governments which have previously signed an MOU with the Regional Office of the Ministry of Law and Human Rights of the province of South Sumatra, namely No. W6.PAS.2.PK.01.06.05-0313 and No. 000/2810/26.8/PN/2014. The signing of the MOU with the city government is aimed at the appointment and assignment of schools for the elementary and junior high school levels, while the signing of the MOU with the provincial government is intended for the appointment of school affairs for the high school level. This MOU has been started in 2014, namely since the creation and implementation of this program, the MOU is periodically renewed every 2 years with the period (2014-2016), (2016-2018), (2018-2020), (2020-2021). Apart from attending school, prison children were also given personality development activities such as computer training activities, sports coaching activities, Pencak silat coaching activities, children's saropal development activities, creative dance development activities, as well as several Islamic activities that are instilled in prison students.

The purpose of this program was to provide education rights for children who were in conflict with the law in the form of formal education, through this formal education the children of LPKA residents could still complete education according to their respective educational levels. This education provided an opportunity for children who were in conflict with the law to experience the same education as their peers without any less or more treatment during the teaching process. This program also presented the same curriculum as formal schools, also equipped with character building, as well as the development of various skills in students. The teachers who taught come from selected state schools.

Data from interviews and observations showed that special service education activities for the filial school program were in accordance with the objectives of the filial school program, namely to provide education rights for children who were in conflict with the law in the form of formal education could complete their education according to their respective educational levels.

\section{Conformity of the program with the vision and mission}

The purpose of this innovation is to provide children with the right to formal education through "Quality Formal Education Services for Children at LPKA Class I Palembang". The main target is Children in Conflict with the Law, by providing access to quality formal education for them, through the Filial School/Formal Education Service for Child Prisoners at LPKA Class I Palembang. This Filial Schools innovation is developed with the hope that: (1) Children in LPKA can attend formal schools like those outside LPKA; (2) Obtaining report cards and diplomas from the main school; (3) Can continue to the next level of education, both school and college; (4) Can get a decent job by using a diploma from a filial school; and (5) parents of children in LPKA feel helped by the existence of a filial school in LPKA; and (6) The disappearance of the stigma against children assisted by the former Class I LPKA Palembang.

In addition to child prisoners, this Filial School also influences other groups as follows: (1) The school where the school in LPKA Class I Palembang continues to encourage inclusive and equitable education through the provision of quality formal education services equal to schools in general. (2) Families/Parents, Children in Conflict with the Law can return to being better individuals so that families are able to accept and treat them properly and fairly. (3) The general public, this initiative has helped to remove the stigma that children in conflict with the law are bad children because the public has seen that former LPKA Class I Palembang children are able to rise up, improve themselves and compete with children outside LPKA.

This filial school which has an educational service initiative in LPKA has been replicated by several regions in Indonesia, namely: (1) Bandung City LPKA has implemented formal education services by establishing schools in prisons, but the existing schools are in the private sector so the weakness is alumni the school will more easily be labeled as a graduate school in prison. (2) LPKA Class II Bengkulu is currently carrying out formal education in LPKA in collaboration with the Bengkulu City Education Office. (3) LPKA Kendari, has fulfilled the right of education for children to go to school for children living in LPKA, but the schools implemented are still in collaboration with PKBM so that the form of education provided is still nonformal.

This filial school is original and the only one in Indonesia, and has received various awards including; The Most Innovative Program from the Central Indonesian Family Planning Association in 2016. Furthermore, this filial school also received an award as the Most Innovative Program from the Coordinating Ministry for Human Development and Culture of the Republic of Indonesia in 2016 and also became the best LPKA that is 
child-friendly based on character and responsive to children's rights from the Ministry of Women's Empowerment and Child Protection Republic of Indonesia in 2017, an inspiring and innovative pilot LPKA from the Ministry of Law and Human Rights of the Republic of Indonesia in 2017.

\section{Cooperation with other parties}

The Special Service Education Program at LPKA is managed by involving several elements, namely: 1) the Education Office; 2) Special Guidance Institutions, 3) Main Schools, 4) Companion Teachers; 5) The Civil Service Teacher, and 6) Society. There are two forms of cooperation, namely first, support for facilities and infrastructure. This support is in the form of providing goods and tools for learning. Second, the support of teachers from the main school.

The organizing elements from the LPKA who are involved in managing the filial school program are: 1) the head of the prison; 2) Head of Development Section and 3) the Civil Service Teacher. The civil servant teacher is a member of the community assigned by LPKA to provide encouragement/motivation, monitoring, and guidance so that the independent learning activities of students can take place effectively and in a coordinated manner. As for the elements of the main school consisting of: 1) Principal; 2) Deputy Principal of the School; 3) Head of Administration; 4) Teachers; and 5) School Committee. For institutional cooperation, among others: 1) Education Office; 2) the Ministry of Law and Human Rights; 3) Ministry of Social Affairs; 4) Ministry of Religious Affairs; 5) National Commission for Child Protection, and 6) Business and Industry.

\section{Input Evaluation}

\section{Availability of facilities and infrastructure}

The availability of space and facilities in LPKA is sufficient to be used as a place for the teaching and learning process of prison students (Andikpas). It can be shown from the results of interviews with respondents who all expressed satisfaction with the facilities and infrastructure provided by LPKA. Space comfort is one of the factors that the information provided can be absorbed properly.

Various efforts have been made to improve the quality of education services at LPKA Class I Palembang, currently repairs and additions to school facilities and infrastructure have been completed, including; 1) Assistance for 1 Classroom Rehab Package for LPKA Class I Palembang School Classes; 2) Assistance of Inventory Goods to support the Implementation of Education in LPKA Class I Palembang.

The facilities for providing skills and expertise at LPKA Class I Palembang were still very minimal. Therefore, the Palembang City Education Office would also in the near future add equipment and supplies for light vehicle workshops at LPKA Class I Palembang for the provision of children in conflict with the law skills and expertise. Facilities and infrastructure, both existing and from various stakeholders, are continuously maintained and improved in quality and quantity so that they can function properly.

\section{Human Resources}

Human resources in question is the competence of educators in special service education at LPKA. There were two teaching staff in the filial school program, namely assistant teachers from the main school who work according to the filial school's learning schedule. The second was the tutor teacher appointed by the head of the LPKA whose job is to assist the accompanying teacher outside of the accompanying teacher's learning schedule.

The data obtained indicate that the human resources who were the facilitators for filial school education have met the required competency criteria. The competence of teachers needed for the filial school program was the same as the competence of teachers in other public schools, namely having professional, pedagogy, personality, and social competencies.

This filial school program has been running for 7 (seven) years, from 2014 until now. The teaching staff who taught were experienced teachers from selected state schools. The material provided is adjusted to the applicable educational curriculum at the main school. Other activities at the filial school were extracurricular activities such as scouts and paskibra, sports activities in the form of futsal, basketball, badminton, and silat. Information from respondents indicates the fact that all the resources involved in the special service education program at LPKA were competent resources in their fields. The drawback was that there were no experts or professionals in the development of expertise skills.

\section{Characteristics of students}

The main objective of the Filial School program at the Correctional Institution for Children (LPKA) is to provide access to formal education for correctional students (Andikpas/students) in LPKA so that their right to formal education was fulfilled. Through this formal education, the children of LPKA could still complete their education according to their respective educational levels. This education provided an opportunity for children 
who were dealing with the law to experience the same education as their peers without any less or more treatment during the teaching process.

For the determination of students, it was done through an identification and assessment process. Identification and assessment in the form of identification of age diversity and the location of the dropout point for prospective students (Andikpas) at LPKA were carried out in order to determine the learning program that needs to be carried out for each individual. This needs analysis is carried out by LPKA together with the Resource center technical team when the correctional student enters and has the status of being assisted by LPKA. Needs analysis through identification and assessment is used as the basis for determining educational learning programs at Filial schools. Not all Andikpas receive guidance through the provision of education in the Filial school program, due to several factors such as: 1). the length of the sentence imposed by the judge (this is because minors are usually sentenced to the lightest possible sentence and imprisonment is the last resort if no other solution is found); 2). absence of a recent diploma or report card for continuing education (dropping out of school).

\section{Program budget}

Filial school is a Formal Education Service for Child Prisoners at LPKA Class I Palembang. Filial school is a breakthrough program that ensures inclusive, quality, and equal education, meaning that it supports learning opportunities, especially for those who are vulnerable to dropping out of school due to legal problems. This program is very innovative because it is the only formal government school established within LPKA and specifically made learning classrooms like formal schools in general. The learning process is carried out referring to the formal school education curriculum, but the teacher's personal approach is more emphasized in the form of coaching and mentoring for mental recovery and building enthusiasm for learning. Administratively, students are registered online in the basic education data system so that there is no difference from other students outside LPKA. The existence of information technology support makes the learning process run more effectively.

The budget needed for the implementation of this program comes from the budget attached to the main school, both from the State Budget in the form of School Operational Assistance funds with an elementary level of Rp. 900,000 per child/year, Junior High School Rp. 1,100,000 per child/year. and Senior High School Rp.1,500,000 per child/year as well as funds sourced from the APBD through the Education Office of the City of Palembang, in the 2020 Local Government Budget, the budget for improving the quality of education in LPKA reached Rp.978,000,000,- plus the budget attached to the LPKA Klas I Palembang as an institution where education is held.

Many parties contributed, starting from the Governor of South Sumatra providing additional income for teachers and providing Umrah rewards for teachers and filial school managers; The Ministry of Education and Culture provides financial assistance, the South Sumatra Province Youth and Sports Office provides sports equipment assistance, PT. PLN (Persero) provides sound system equipment assistance, BRI provides financial assistance and computer laboratory equipment, reading books from regional libraries, and so on.

\section{Process Evaluation \\ Program Implementation}

This program started when the LPKA raised the issue of the lack of educational services for children in conflict with the law in LPKA Class I Palembang in 2014, where the children's learning participation rate was only $14 \%$ through non-formal education. Responding to this condition, the Palembang City Education Office initiated the establishment of a Formal School at LPKA to ensure the implementation of an orderly learning process and served by competent teachers. The following steps were then carried out: (1) Identification and assessment of children in LPKA Class I Palembang; (2) Education Management Arrangements; (3) Student Admission; (4) Regulating Curriculum and Teaching Materials; (5) The implementation of learning is carried out in a classroom like a formal school outside LPKA. However, the teacher uses a personal approach which is considered more effective, because it is able to build children's trust and feel comfortable with the attention of the teacher; (6) Assessment and Graduation; (7) Educators and Education Personnel: (a) Educators are teachers, and (b) Education Personnel; (8) Educational Infrastructure Facilities: (a) Activity Place Infrastructure Learning, and (b) Learning and Other Supporting Facilities; (9) Cooperation Institution. Cooperation is carried out with various relevant stakeholders, such as government agencies, state-owned enterprise, regional- owned enterprise, institutions, and NGOs.

In order to ensure quality, it is necessary to carry out monitoring and evaluation in the form of: (1) Academic supervision, with targets; administrative completeness, learning process, administration; (2) Managerial internal supervision, with objectives; to support the achievement of standards for educators and education personnel, infrastructure, management, and financing. 
This monitoring is carried out by: (1) School Supervisors; conduct supervision/supervision of teaching and learning activities; (2) Education Office; monev on the implementation of education in general; (3) Regional Office of the Ministry of Law and Human Rights of South Sumatra Province; monev on activities and availability of school infrastructure.

The evaluation and results of monitoring activities will be input for institutions and related parties to improve the quality of services, one the results of the evaluation is to transfer children facing the law who are still detained in Rutan/Lapas in the South Sumatra Region to be transferred to LPKA Class I Palembang considering the number of children in LPKA is decreasing.

\section{Product Evaluation \\ Evaluation}

Assessment of student learning outcomes in the filial school program includes the competence of attitudes, knowledge, and skills which is carried out in a balanced manner so that it can be used to determine the relative position of students to the minimum learning completeness that has been determined. Assessment of learning outcomes is carried out in the form of: 1) daily assessment, mid-semester assessment, and end-semester assessment conducted by accompanying teachers under the coordination of the main school; 2) the National Standard School exam is conducted by the main school.

The increase in the level of students is determined by the increased criteria that apply at the main school. Special service students are declared to have passed if they have passed the school exam/education unit exam according to the criteria applicable at the main school. For students who have not met the competencies/have not passed, they are required to re-take the exam the following year.

\section{Program success}

The success of the program is seen from the benefits felt by Andikpas and the achievement of program objectives. The children of LPKA residents can still complete their education according to their respective educational levels. Children who are in conflict with the law can experience the same education as their peers without any less or more treatment during the teaching process. Every year, the Filial school program has succeeded in bringing its students to continue at the next higher level of education. Graduation Data of LPKA Class I Filial School Students of Palembang can be seen in Table 1.

Table 1. Graduation Data of LPKA Class I Filial School Students of Palembang

\begin{tabular}{clccc}
\hline \multirow{2}{*}{ No } & & \multicolumn{2}{c}{ Year } & \\
\cline { 3 - 5 } & & $\mathbf{2 0 1 8}$ & $\mathbf{2 0 1 9}$ & $\mathbf{2 0 2 0}$ \\
$\mathbf{1}$ & Elementary School & 4 & - & 1 \\
$\mathbf{2}$ & Junior High School & 11 & 6 & 4 \\
$\mathbf{3}$ & Senior High School & 14 & 5 & 11 \\
\hline
\end{tabular}

Furthermore, based on the monitoring results, most of the children who have completed their education at LPKA have been able to improve their welfare. Based on the results of monitoring, some children who have completed their education at LPKA continue their education to a higher level. Andikpas were mostly workready oriented, few wanted to go to college. Andikpas filial schools like students in other public schools also made achievements, including having participated in competitions between students inside and outside LPKA. Among them: (1) $1^{\text {st }}$ place in the Correctional Student Literacy Competition in the Story Telling Category with the title "Dunia Kotak" (World of the Box) at the Ministry of Law and Human Rights of the Republic of Indonesia; (2) Selected Writers in the National Short Story Competition themed "Kesempatan Kedua" (second chance) organized by Young Writers Publisher in Surabaya; (3) Contributors to the Poetry Contest with the theme meilatinahpati organized by the Indonesian Literary Community; (4) Selected Authors in Poetry Writing Contest with the Title "Tak Kan Kubiarkan Hati ini Menangis Lagi" (I Won't Let This Heart Cry Again) by One Piece Media Publisher; (5) Favorite Writer in the Poetry Creation Event themed "Ibu Pertiwi" (Motherland) organized by Bukit Tinggi Ink Scratch; (6) Palembang City Level Karate Competition; (7) Participate in the National Caring Children Gathering in Jakarta; (8) Participating in the Indonesian National Dialogue with Equal Dignity in Jakarta.

The results of the research evaluation using the CIPP method found that the fulfillment of the right to education for children in conflict with the law through the Filial School Program at LPKA Kelas 1 Palembang has been going well. Based on the monitoring results, most of the children who have completed their education at LPKA have been able to improve their welfare. Some of them working in government agencies, private companies, self-employed, and temporary workers. Approximately most of children who have completed their education at LPKA continue their education to a higher level. Andikpas are mostly work-ready 
oriented, few want to go to college. Andikpas filial schools as students in public schools also made achievements, including having participated in competitions between students inside and outside LPKA.

The implementation of coaching carried out by LPKA such as formal and informal lessons aimed at school education, so that when they leave later they can face their future with hope. In addition, the system cannot force anyone to change, unless the individual is willing to change, the institution only supports them by providing teaching but success can be achieved if the individual desires (Inderbitzin, 2006). Coaching or guidance is a means that supports the success of the state in making prisoners a member of society. Child Correctional Institutions play a role in fostering prisoners, who treat prisoners to be better, what needs to be fostered is the prisoner's personality, raises a sense of self-esteem and develops a sense of responsibility to adjust to a peaceful and prosperous life in society, so that the potential to become a human being personal and high morals (Mawangi, 2019).

The results of the evaluation found several supporting factors for this Filial School Program, including the competence of human resources, especially human resources in charge of providing learning in this case the civil servant teachers, and accompanying teachers who are very competent in their fields. Educators who provide learning materials on average have worked in the main school for more than 15 years, so they have mastered the understanding of the characteristics of students and learning materials. The educational background of the educators as facilitators is quite competent, both formal education and training and workshops that are followed. Allof the teaching staff are at the undergraduate level and some are at the graduate level. Cooperation with the main school and stakeholders is well established. LPKA provides support in the form of facilities and infrastructure to support the learning process and equipment needed for this program. It is evident from the existing facilities have increased from year to year both in terms of quantity and quality. The facilities and infrastructure for the filial school program are also quite adequate, the results of interviews with all respondents stated that they were satisfied with the facilities and infrastructure provided. LPKA provides facilities for the implementation of this activity by procuring goods and equipment for activities according to the needs of students based on proposals from the main school. Network and internet facilities in the computer laboratory room are available smoothly. A comfortable classroom is also one of the supporting factors for Andikpas in participating in the learning process.

The evaluation results also found several inhibiting factors for this Filial School Program, namely: (1) Andikpas were mostly work-ready oriented, few wanted to go to college. To overcome this obstacle, this filial school program seeks to be able to provide science and technology subject matter based on expertise skills by involving the cooperation of the Education Office, Correctional Institutions for children, Course Institutions, Fankei Skills Education Institutions, UPT Job Training Center Transmigration Productivity, and Skills Development, Manpower Office; (2) The facilities for providing skills and expertise are still very minimal. To overcome this obstacle, this filial school program is seeking to provide facilities to support practical skills-based workshops, machining, and other activities by involving the cooperation of the Education Office, Correctional Institution for Children, Course Institute, Fankei Skills Education Institute, UPT Job Training Center. Transmigration Productivity and Skills Development, Manpower Office; (3) There are no experts or professionals in the development of skills; To overcome this obstacle, this filial school program is seeking to provide experts or instructors of vocational skills education by involving the cooperation of the Education Office, Correctional Institution for Children, Course Institutions, Fankei Skills Education Institutions, UPT Work Training Center for Productivity and Transmigration Skills Development, Employment agencies. (4) There are Andikpas who cannot attend Formal Education. To overcome this obstacle, this filial school program is seeking to provide the Package A Equivalence Education Program (Elementary School Level), Package B (Junior High School Level), and Package C (High School Level) by involving the cooperation of the Education Office, Correctional Institution for Children.

\section{Conclusions}

Based on the description of the research results discussed in the previous chapter, it can be concluded that the Filial school program in providing formal education rights for children through Quality Formal Education Services for Children at LPKA Class I Palembang has been going well. The children of LPKA residents can still complete their education according to their respective educational levels. Children who are in conflict with the law can experience the same education as their peers without any less or more treatment during the teaching process. This program also presents the same curriculum as formal schools, also equipped with character building, as well as the development of various skills in students. Some of the supporting factors for this Filial school program include HR competence, good cooperation with main schools and stakeholders, support in the form of facilities and infrastructure to support the learning process and equipment needed for this program; the availability of comfortable teaching and learning rooms, library rooms, computer laboratory, 
and others. Some of the inhibiting factors for this Filial School Program were: (1) Andikpas were mostly workready oriented, few wanted to go to college; (2) The facilities for providing skills and expertise were still very minimal; (3) There were no experts or professionals in the development of skills; (4) There were Andikpas who cannot attend Formal Education. The suggestion in the CIPP evaluation research is that in the future the Filial school program at LPKA is recommended to add infrastructure in the vocational field so that students who want to enter the vocational level can be accommodated. The second thing is to strive for the fulfillment of equal rights for children who are "inside" the facilities provided by the government. One of them is getting a KIP (Kartu Indonesia Pintar) card which is a form of government program to help people get a proper education.

\section{Acknowledgments}

We would like to thank to Rector Universitas PGRI Palembang and Universitas Bengkulu, Dean of Education Faculty Universitas Bengkulu and Chief of Doctor of Education Study Program. We would like to thank all those who have contributed to this research.

\section{References}

Angelina, N. (2013). Pemenuhan Kebutuhan Hak Pendidikan Formal Bagi Anak Yang Berhadapan Dengan Hukum Sebagai Upaya Mewujudkan Kota Layak Anak Di Surakarta. Sosialitas; Jurnal Ilmiah Pend. Sos Ant, 3(1).

Estriyanto, Y. (2016). A Review of Indonesian Pre-Service Teacher Certification Policy from the Point of View of the Philosophy of Vocational Education. Prosiding ICTTE FKIP UNS 2015, 1(1).

Bappeda Litbang. (2019). Rencana Kerja Pemerintah Daerah Kota Palembang Tahun Anggaran 2020. Bappeda Litbang (Badan Perencanaan Pembangunan Daerah Penelitian dan Pengembangan) Pemerintah Kota Palembang.

Constitution of the Republic of Indonesia 1945.

Djamin, M. N. (2013). Pimpinan Panja RUU Sistem Peradilan Pidana Anak Komisi III DPR RI, Anak Bukan Untuk Dihukum. Jakarta: Sinar Grafika.

Fattah, N. (2004). Landasan Manajemen Pendidikan. Bandung: PT. Remaja Rosdakarya.

Gunung, I. N., \& Darma, I. K. (2019). Implementing the context, input, process, product (CIPP) evaluation model to measure the effectiveness of the implementation of teaching at Politeknik Negeri Bali (PNB). International Journal of Environmental and Science Education, 14(1), 33-39.

Hasan, H. (2009). Evaluasi Kurikulum, cetakan kedua. Bandung: Remaja Rosdakarya.

Hidayat, B. (2010). Pemidanaan Anak di Bawah Umur. Bandung: PT Alumni.

Inderbitzin, M. (2006). Lessons From a Juvenile Training School: Survival and Growth. Journal of Adolescent Research, 21(1), 7-26.

Law Number 20 of 2003

Law Number 12 of 1995 about Penitentiary

Limpo, I. Y., Bachri, S., Ilmar, A., \& Patittingi, F. (2018) Potret of Basic Education in Indonesia (A Legal Political Study). Journal of Law, Policy and Globalization, Vol. 69.

Mawangi, R. K. (2019). The Role of Family in Dealing with Juvenile Delinquency. Open Journal of Social Sciences. Open Journal of Social Sciences, 7(3), 52-63.

Nugroho, G. W. F., \& Novianto, W. T. (2018). Perlindungan Hak-Hak Anak dalam Proses Pembinaan di Lembaga Pembinaan Khusus Anak Kelas I Kutoarjo. Recidive, 7(3), 262-274.

Sopandi, E., \& Khasanah. (2020). Evaluation of Implementation of Inclusion Education Programs in Madrasah Ibtidaiyah Badrussalam Surabaya. Akademika, 9(1).

Stufflebeam, D. L. (2003). The CIPP model for evaluation. In D. L. Stufflebeam \& T. Kellaghan (Eds.), The international handbook of educational evaluation (Chapter 2). Boston, MA: Kluwer Academic Publishers.

Sugiyono. (2016). Metode Penelitian Kuantitatif, Kualitatif, dan R\&D. Bandung: Alfabeta.

Sukardi. (2014). Evaluasi Program Pendidikan dan Pelatihan. Jakarta: PT. Bumi Aksara.

Supeno, H. (2010). Kriminalisasi Anak Tawaran Gagasan Radikal Peradilan Anak Tanpa Pemidanaan. Jakarta: PT Gramedia Pusaka Utama.

Tambunan, R., Ablisar, M., Mulyadi, M., \& Ikhsan, E. (2015). Perlindungan Hukum Terhadap Anak yang Berkonflik dengan Hukum dalam Memperoleh Pendidikan. USU Law Journal, 3(1), 123-135.

The Regulation of Minister Education Number 49 of 2014.

Widoyoko, E. P. (2009). Evaluasi Program Pembelajaran: Panduan Praktis Bagi Pendidik dan Calon Pendidik, Yogyakarta: Pustaka Pelajar. 
Zhang, G., Zeller, N., Griffith, R., Metcalf, D, Williams, J., Shea C., \& Misulis, K. (2011). Using the Context, Input, Process, and Product Evaluation Model (CIPP) as a Comprehensive Framework to Guide the Planning, Implementation, and Assessment of Service-learning Programs. Journal of Higher Education Outreach and Engagement, 15(4), 57-63. 